\title{
PROCEDIMENTO LÍRICO EM UNS OLHOS DE RESSACA
}

\section{Roberto Sarmento Lima *}

Resumo: Compreensão do procedimento lírico-discursivo, cuja manifestação, alheia a noções de forma, gênero e espécie literários em que ele venha a se configurar, se realiza através da dramatização da linguagem vista como acontecimento ou evento, pelo qual imagens e efeitos estilísticos, selecionados para a constituição da cena lírica, operam o fingimento que orienta o plano da construção do texto literário, em um recorte auto-reflexivo encontrado nesse tipo de linguagem.

Palavras-chave: Lirismo; acontecimento ou evento; discurso; autoreflexibilidade da linguagem; procedimento; visão

\section{Por uma concepção de lirismo}

Deixando-se de lado por um instante o risco delimitador dos gêneros literários - algo que cada vez mais vem sendo relativizado pelo reconhecimento de que a circunscrição do texto a modelos prévios terminou por amortecer o interesse analítico-interpretativo, em razão de um mundo dominado por um processo acelerado de mudanças sociais e culturais em que já não cabe a definitivização de um esquema rígido -, resta ainda reafirmar, pelo menos desde a instauração da modernidade, a noção de autonomia da obra literária, cujos princípios de legibilidade gozam de independência em face de outros discursos e de classificações literárias mais empedernidas. Nesse sentido, ainda ressoam nítidas as palavras de Oscar Wilde no

- Professor Doutor da Faculdade de Letras da Universidade Federal de Alagoas, na qual atua também como professor-pesquisador do Programa de Pós-Graduação em Letras e Lingüística, no setor de Literatura Brasileira. Atualmente orienta pesquisa inscrita no Programa de Iniciação Científica da Ufal, sobre Machado de Assis ( $O$ romance escreve a história no Brasil do Segundo Reinado). 
prefácio a $O$ retrato de Dorian Gray, espécie de testamento da modernidade:

Não existe livro moral nem imoral. Os livros são bem ou mal escritos. Eis tudo.

[...]

Pode perdoar-se a um homem a criação de uma coisa útil, contanto que ele não a admire. A única justificativa para a criação de uma coisa inútil é que ela seja admirada intensamente.

Toda arte é absolutamente inútil.

Alardear a autonomia tornou-se o slogan emblemático dos novos tempos e em todas as áreas do fazer e do pensamento reflexivo, algo considerado natural em uma sociedade capitalista, que produz para o mercado e cuja contradição máxima, a separação entre o capital e as formas concretas de trabalho que geram esse capital, precisa ser disfarçada.

O que esconde, então, o texto literário? Em nome de que se erige sua propalada autonomia? A defesa do primado dos jogos verbais, das sonoridades evanescentes e da constituição de uma "realidade" superior e alheia ao mundo vulgar do comércio - em nada um desejo de purificação inocente, mas, muito pelo contrário, uma resposta ao instinto de autopreservação do estético nesse tipo de sociedade que, por sua vez, é segregadora - levou muito espírito elevado a acreditar religiosamente na sacralidade desse gesto, como exemplifica Olavo Bilac:

Porque a Beleza, gêmea da Verdade,

Arte pura, inimiga do artifício,

É a força e a graça na simplicidade.

Tal atitude, invadindo o século $X X$, não ficou restrita, nem poderia ficar, ao campo literário mas estendeu-se igualmente à atividade teórico-crítica desse campo de estudos: caso dos formalistas, dos estruturalistas, dos new críticos. Infeliz daquele que precisa declarar-se acima do mundo dos homens!

Nesse contexto de valores setorizados, a autonomia é um ideologema que não cansa de clamar sua inocência, mas que, sob um olhar crítico atento, não pode deixar de ser visto como uma forma 
historicamente possível do ser estético, principalmente porque costuma ser pensado como a tendência do texto literário à auto-reflexibilidade, processo tornado agudo (mas não exclusivo) a partir de então. Nada mais enganosa a absolutização desse argumento: sob a capa do auto-referir-se, oculta-se essa variante vinculada aos desígnios da modernidade, que, historicamente definida, informa a conexão entre a autonomia do texto e sua imagem de Narciso, pela atitude metalingüística, entre outros recursos, como estratégia de resistência (BOSI, 1977, p. 144-149).

Mas o que interessa particularmente aqui é que, não sendo sempre isso, a atitude de reflexão realizada no código e pelo código é condição de manifestação do lirismo. E, dependendo do tempo histórico em que ocorra, revela-se desse ou daquele modo.

O que dizer, então, do supra-sumo dessa maneira de ser e pensar - o lirismo? Em geral confundido com uma atitude de exercício de profunda subjetividade no modo de encarar o real, o lirismo tem sido apreciado ora como uma modalidade de constituição literária, espécie adjetiva que, como quis Emil Staiger (o lírico é um "estilo"), se realizaria em obras díspares, independentemente da camisa-de-força do gênero; ora como o desprezo pelo circunstancial, pela objetividade do mundo e, em contrapartida, como o realce de uma visão pessoal e extremada das coisas. Ou seja: o lirismo seria, nessa percepção, um recorte de realidade feito por uma sensibilidade poderosa, apenas alçada, desde a modernidade, a um patamar de independência em relação a outros valores que não os literários sempre uma tentativa histórica de encarar a questão. Daí a tendência de opor um lirismo moderno a um lirismo romântico, por exemplo.

$\mathrm{O}$ argumento a ser exposto aqui segue outro rumo: o lirismo é um procedimento discursivo, na verdade autoconsciente, que nem se confunde com o gesto narcísico de a modernidade entender a autonomia literária, nem, muito menos, lembra a dependência do recorte literário a uma voz privilegiada, como se na narrativa, por exemplo, mesmo naquela mais impessoal de terceira pessoa, não houvesse uma voz personalizada a revelar o mundo, e até a fazê-lo explodir. Isso leva ao ultrapasse da própria concepção de gênero, a que não se subordinaria, aqui, a questão do procedimento lírico, cuja maneira de ser, conforme julgo, não se esgota no mapeamento das espécies catalogadas pela história e crítica literárias nem, ainda, no 
princípio de supervalorização do eu e da emocionalidade na organização dos fatos, conforme em geral tem sido observada essa questão. Mas, como afirma Pinson (1999, p. 36),

L'idée de lyrisme ne doit pas, toutefois, prêter à équivoque. [...] il n'est nullement synonyme d'effusion subjective. Car il ne s'agit pas ici de jouer de la corde des sentiments pour tenter d'émouvoir le lecteur, mais d'abord de mettre sous tension la lyre (le langage), de telle sorte que sous l'effet du poème l'âme du lecteur retrouve ardeur et vigueur.' (grifo meu).

A precedência, pois, do comportamento da linguagem em relação ao desfiar da emoção é algo que deve ser investigado no exame do problema do lirismo que ora se coloca. Assim, o lírico, dimensão da linguagem literária, é menos uma máquina que vise à interiorização do mundo focalizado do que propriamente um modo ou uma atitude que o sujeito da enunciação toma para si com a pretensão de produzir, ou representar, um efeito discursivo, ${ }^{2}$ independentemente

1 "A idéia de lirismo não deve, entretanto, prestar-se a um equívoco. [Lirismo] não é de modo algum sinônimo de efusão subjetiva. Pois não se trata aqui de fazer vibrar a corda de sentimentos para tentar comover o leitor, mas, antes de tudo, de pôr em tensão a lira (a linguagem), de tal maneira que, sob o efeito do poema, a alma do leitor encontre, de forma renovada, ardor e energia" (Tradução e grifo meus).

2 É bom deixar claro que, quando falo de caráter discursivo do procedimento lírico, não me refiro à capacidade de linguagem organizada em discurso no seu sentido mais comum, de pensamento construido em frases ordenadas. Por isso, para este ponto de vista não vale o que disse Vitor Manuel de Aguiar e Silva sobre a experiência poética concretista: "O concretismo exacerbou o antidiscursivismo da lírica até ao extremo limite, pretendendo substituir a sintaxe verbal por uma 'sintaxe virtual' [...] reduzindo as palavras do poema ao mínimo [...]" (SILVA, 1976, p. 234). Discursivo, neste artigo, refere-se à capacidade que o texto tem de contextualizar sua intenção de produção dentro da própria construção de sentidos poético-literários, misturando-se aos temas (o que nada tem a ver, como já disse, com o arrogante sentimento de autonomia do texto). Nesse sentido, discurso é um acontecimento de linguagem, pelo qual o lirismo manifesta sua intenção produtiva no momento mesmo em que o texto se escreve. Veremos isso de modo mais detalhado na terceira seção deste artigo. 
da utilização dos recursos externos (verso ou prosa) através dos quais o texto seja composto. Desde Aristóteles, aliás, sabe-se que o uso do verso não faz de ninguém poeta, muito menos um lírico (de um ponto de vista estritamente histórico, o comentário do filósofo incide sobre a compreensão, própria de sua época, de que tanto o chamado poeta quanto o físico se serviam, naquele momento, desse artifício de escrita). Mas, mesmo hoje, quando quase ninguém, a não ser o poeta, se arriscaria a escrever em verso, a advertência continua válida - pois é o processo que identifica e perfaz a natureza do texto que habitualmente entendemos como literário. Para a constituição desse quadro dilui-se a força de ideologemas como "autonomia", "liberdade criadora", "individualismo", "primado do eu"; e só uma mente acostumada a pensar historicamente pode perceber a fragilidade desses conceitos em geral tomados como meros caprichos estéticos.

Também, em troca, não há por que - em nome da rigidez epistemológica derivada, às vezes, do cruzamento de outras disciplinas (história, sociologia, psicologia etc.) com a área específica dos estudos literários - se deva defender a submissão do elemento estético a visadas teóricas externas. Tal integração é saudável, e necessária, quando ocorre de fato, não uma superposição ou uma subsunção, mas uma correlação entre os diversos pontos de vista que se apresentem para dar conta da leitura do texto, que não deve, pois, ser tomado como epifenômeno.

Não terá sido por essa tendência, atual, de submeter o literário às correntes várias do pensamento, sem respeitar as legítimas prerrogativas da interdisciplinaridade, que se ouvem, ainda hoje, vozes que vêm em defesa da especificidade da área?

[...] No momento atual a literatura está sendo questionada em sua produção e em sua recepção, encontrando-se ameaçada em seus próprios fundamentos. Como atividade autônoma, a literatura data de meados do século XVIII [...].

Avaliadas a partir de posições ideológicas, as obras literárias foram afogadas na enxurrada dos "estudos culturais", que têm pouco de estudo e pouco de cultural, por recorrerem a um ecletismo não interdisciplinar mas adisciplinar, e por se aplicarem a objetos cujo valor é indeterminado (PERRONE-MOISÉS, 2000, p. 347-348). 
Mesmo em um crítico e teórico de formação sociológica, como Antonio Candido, é tocante, no entanto, como ele confere prioridade à dimensão assim denominada literária:

[...] saímos dos aspectos periféricos da sociologia ou da história sociologicamente orientada, para chegar a uma interpretação estética que assimilou a dimensão social como fator de arte. Quando isto se dá, ocorre [...]: o externo se torna interno e a crítica deixa de ser sociológica, para ser apenas crítica. [...]

[...] E nós verificamos que o que a crítica moderna superou não foi a orientação sociológica, sempre possivel e legítima, mas o sociologismo crítico, a tendência devoradora de tudo explicar por meio dos fatores sociais (CANDIDO, 1976, p. 7; os grifos são do autor).

É nesse sentido que defendo a noção de lirismo como um procedimento que avulta em sua legibilidade própria; e dizer isso, reconhecer o princípio heurístico dessa mesma legibilidade, não implica situar a questão fora dos limites da história, como a assertiva parece sugerir - pois foi só com o contexto romântico que poesia e lirismo, praticamente tomados como sinônimos, passaram a constituir eleição de mundo particular, criado por uma voz igualmente particular, sensível, ansiosa por evasão e deliberado auto-isolamento. E, ultrapassado esse periodo, urge mais uma vez rever a questão, cuja legibilidade reclama novos direcionamentos. O que aqui se busca é entender as faces variantes dessa noção dentro dos limites da história e admitir que determinados conceitos de lirismo, como esse do ambiente romântico, são, na verdade, históricos e, portanto, redirecionáveis, uma vez que só com a modernidade, com a produção para o mercado, que defende a autonomia da coisa em face do seu produtor - inversão fantástica das relações entre coisas que efetivamente operam no mundo, criando a ilusão de autonomia -, é que se pode pensar na literatura como reino de produção de objetos autônomos e, decorrência disso, o lirismo como departamento desse reino. Não o são assim, naturais, essas relações, mas assim se apresentam; e esta é a forma fenomênica que preside à sua produção e compreensão.

O lirismo, se visto, pois, não como um conceito que se atém exclusivamente ao moderno nem como recorte de um eu privilegiado 
que recusa a representação do mundo objetivo como tal, mas, antes, como uma produção de sentidos que se materializa na tessitura do texto - repito, em verso ou não -, ensaiando a razão de ser dessa tessitura, oferece-se como a instauração da própria condição do texto (o que pode ser confundido com estratégia moderna de representação e de exibição de sua autonomia, mas que não é, sob pena de patinar tautologicamente nesse terreno).

É aceitável que o texto literário, sobretudo o da modernidade para cá, é aquele que, programaticamente, exibe seu material, põe a nu sua construção, revela sua consciência. O lirismo, se entendido como procedimento consciente, é algo que, contendo em parte esse significado, ultrapassa, porém, tal tendência, pois, conjugado a esse princípio, está o conceito de discurso, pelo qual se contextualiza a produção do fingimento literário. Notemos que no texto literário há camadas de dizer. Uma delas, que nos interessa na abordagem do lirismo, presentifica a intenção pela qual o texto constitui sua realidade sígnica. Vejamos, ainda que apressadamente, estas estrofes de Gregório de Matos:

Não vira em minha vida a formosura, Ouvia falar nela cada dia, E, ouvida, me incitava, e me movia

A querer ver tão bela arquitetura:

Ontem a vi por minha desventura

Na cara, no bom ar, na galhardia

De uma mulher, que em Anjo se mentia;

De um Sol, que se trajava em criatura

Do ponto de vista do enunciado, o eu poético afirma a necessidade de homenagear a beleza de uma mulher que simboliza o ideal (clássico, bem entendido) de perfeição; mas, na camada enunciativa que tece, revela o esforço que essa necessidade requer para a composição se perfazer, declarando, pois, o quanto há de artificioso nisso (pensando-se que, para o barroco, o natural e o artificial se cruzam dilematicamente, inclusive - ou sobretudo - para a realização da sua expressão). Tal criatura, fica claro logo, é uma "mulher" que de "Anjo" não tem nada, pois "se mentia" (dizer que o anjo se mente é negar a legitimidade da própria imagem escolhida, "Anjo"); muito menos é ela um "Sol", pois "se trajava em criatura" (o 
traje é outra mentira, pois de uma vestimenta se pode livrar quando se quer). O jogo de aparências e realidades íntimas, aliás, é o maior produto do ilusionismo barroco, que, ao mesmo tempo que reafirma sua sinceridade, apresenta despudoradamente seu engano.

Assim, imiscui-se, no soneto de Gregório, na representação do objeto escolhido para tema (a beleza excepcional dessa mulher), a própria representação dos bastidores da ficção e do lirismo: para o barroco, ser lírico é apontar para as sutilezas do raciocínio da ilusão silogística, um silogismo falso, como apontam alguns exegetas do nome "barroco" (Velázquez, com As meninas, não estaria justamente querendo dizer isso, ao fazer crer que quer pintar as meninas e não o rei e a rainha da Espanha, seu verdadeiro objeto?); para o romântico é declarar a insuficiência dos recursos ("Frouxo o verso talvez, pálida a rima"); para o moderno, é afirmar que o centro não existe mais e que a linguagem literária, por isso, escapa ao controle do sujeito autoritário, não visto mais como criador ou vate. Já o pós-moderno constrói uma linguagem que não é mais sequer margem; é uma fuga para todos os lados do dizer, numa errância sem busca. Em Benjamin, de Chico Buarque, por exemplo, a personagem feminina não sabe para onde vai nem o que quer, e o discurso que a enforma, assim como é constituida tal criatura, cria-se a si mesmo sem direção, em verdadeira fuite en avant, como o pontua Perrone-Moisés (2000, p. 250).

Desse modo, pretendo encarar o lirismo em sua natureza dúplice: contra os discursos correntes, marca a diferença em relação a tais discursos por querer dizer a que veio; já a favor da literatura, revela sua concepção do produzir literário, neste ou naquele momento da história. O que é histórico nessa concepção de lirismo é o modo como ele, o discurso, se comporta de tempos em tempos; sua permanência, porém, é o próprio procedimento, ou seja, o princípio formal que o constitui.

Que conceito é este, discurso? O discurso literário, entendido desde Aristóteles como ação da "poiésis"/"mimesis" - mimesis não se reduz a ser imitação, mas é um processo que leva em conta a imitação, superando-a no entanto, e que se apodera do mundo do qual parte -, vem a ser, antes de tudo, produção ("poesia", poiésis, entre os gregos antigos, não era justamente isso?). E não teria sido isso que Aristóteles teria querido dizer? Que sua "poiésis" é uma teoria do lirismo (já que 
"poesia", para um grego daquela época, era algo mais do que o que entendemos em geral por poesia)?

Produção, palavra vária, tanto se dá no sentido de construção, execução (como disse Aristóteles), quanto, hoje, no sentido já internalizado pelo capitalismo: um fazer humano que se realiza, independentemente de o surpreendermos, ou não, no interior de uma práxis fetichizada. Trata-se, assim, de sentidos nascidos em trilhas distintas da História as quais terminam, no entanto, por convergir e cujos movimentos, curiosamente, a "razão prática" separa, reduzindo cada pólo a um mundo de pseudoconcreticidades (KOSÍK, 1976), no qual, obscurecida a contradição, prevalece o plano do fenômeno em detrimento do da essência da coisa. Aliás, a defesa alucinada da autonomia literária é a justa vitória desse mundo em que aparência e essência se confundem ou um vale pelo outro. Foi também nesse conflito de aparências e essências posto a nu pela análise da realidade capitalista que, segundo Lukács $\left(197^{*}\right)$, se aparelhou o romance moderno, forma artística que problematizou, dilematicamente, a tentativa de restauração da totalidade vilipendiada. Discurso, produção, mimesis, totalidade ou totalidade ameaçada e perdida: faces do lirismo?

Para este estudo, discurso é indissociável de certo posicionamento diante do mundo, tanto para combatê-lo, quanto para aceitá-lo; reprimi-lo, resistir a ele, domesticá-lo. Discurso há de ser entendido como linguagem que se põe em ação, do ponto de vista performativo: dizer o mundo é, em literatura, especialmente na produção do lirismo, realizar o texto-mundo. (Mimésis, para Aristóteles, não é isso?) O lírico foi concebido por certa tradição dos estudos literários como aquele estado ou aquela entidade de expressão verbal que, confiante no poder da sua subjetividade, vê sua alma maior do que o mundo, espécie de correlato do herói do tipo de romance definido por Lukács como "romantismo da desilusão". Apenas nesse tipo romanesco, a objetividade do mundo perde força quando confrontada com a inteireza do eu do herói, que foge então do enfrentamento da presumida resolução dos antípodas da existência c pretende substituir a ação pela interiorização da mesma ação. Seria essa modalidade de romance apontada por Lukács, digamos assim, menos épica? Mais lírica, portanto? Mas sabemos que o lírico nem sempre interioriza definitivamente o mundo, mas recua também diante 
dele: Carlos Drummond de Andrade, em "Poema de sete faces", o primeiro da coletânea de Alguma poesia (1930), declara, subordinando a realidade ao sentimento,

Mundo mundo vasto mundo, mais vasto é meu coração.

para depois, enfaticamente, contrariar a capacidade germinativa do próprio ego e, ato contínuo, acusar sua fraqueza psicológica, no poema "Mundo grande", que fecha Sentimento do mundo, seu livro de 1940:

Não, meu coração não é maior que o mundo.

É muito menor.

Nele não cabem nem as minhas dores.

Contradições do lirismo? Efetivamente não; antes, uma avaliação do que se diz no poema - traduções do lirismo em momentos diversos da história e do percurso de amadurecimento de certa consciência lírica. Por estar situado em solo histórico, o discurso produz um sentido contra o mundo ou a favor dele; e o lírico é lírico não simplesmente porque questiona o mundo e sua relação com o sujeito que indaga - mas porque se perscruta, porque acusa o papel do sujeito, que, no texto, se interroga, interroga o mundo via literatura e nomeia e renomeia o mundo. Portanto, não porque faz da subjetividade o reino totalitário da poesia, mas porque discute, problematiza o próprio enunciador, a função desse enunciador; e por isso é que, mesmo dizendo coisas velhas, as transforma em dados novos. O que parece, pois, ser uma apresentação do tema do poema o leitor não-especializado assim o diria - é, antes, um questionamento de por que se diz tal coisa no momento em que se diz (como vimos há pouco no soneto de Gregório de Matos: por que o eu lírico diz que aquela mulher é Anjo se, de antemão, já se sabe que ela não o é, senão porque foi necessário, renomeando o ser mulher, justificar o caráter barroco de tal soneto?).

Eis aí uma regra do lirismo que começa a se delinear: o enunciador (tanto faz se é do poema ou se é do romance) problematiza o dizer literário do texto, numa expressão que irrompe no tecido enunciativo, fazendo-nos ver o que não víamos, o que a camada do enunciado nem sempre permite perceber. 
Como detectar isso em um texto literário, como entender o processo do lirismo com base em uma relação que não oculte a contradição - aparente contradição - entre o tema e a enunciação, antes a revele?

\section{O lirismo nasce do primeiro olhar}

Em uma passagem bem conhecida de Dom Casmurro, Machado de Assis dramatiza uma cena em que toma vulto o procedimento de que o lirismo e a poesia são ações - espécie de escolha metodológica com que se define, ao menos em algum momento da grande extensão do texto, o lugar de onde se visualiza o processo de composição pondo-se a nu. Trata-se, nesse romance, principalmente do instante em que Bentinho adolescente, rememorado pelo torturado Dom Casmurro, prende fixamente seu olhar no olhar de Capitu e procura entender as razões do comentário que José Dias tinha feito sobre ela, chamando a atenção do rapaz para certos "olhos de cigana obliqua e dissimulada". face a face:

Num dado momento da narrativa, Bentinho e Capitu ficam

\section{- [...] Deixe ver os olhos, Capitu.}

$\mathrm{Ah}$, sempre os olhos! Platão, ainda que tenha posto em xeque a percepção sensivel e as próprias manifestações do corpo, para ele mundo baixo e enganoso, forjou, segundo seu inconsciente poético, a Idéia como imagem: eidós e seu correlato latino video já revelam, desde o étimo, a força da visão. Uma visão renovada, pois. Do contrário, não haveria nisso extraordinariedade, não haveria força fundante nem produção de sentidos. Ver o mesmo é revisitar (e visita, por sua vez, se enraíza em viso, como não?). Na literatura, então, segundo minha hipótese, só emergiria o processo lírico quando parecesse que o mundo está sendo visto pela primeira vez (como ensina o exemplo platônico). Ou, nas palavras de Pinson (1999, p. 33): "La póesie est pour nous comme une source de fraîcheur, elle accroît notre vitalité".

3 "A poesia é, para nós, como uma fonte de frescor, ela aumenta nossa vitalidade." (Tradução minha) 
Não teria sido por isso que Édipo, num sacrifício supremo, arrancou os olhos? Ou seria, como determinou Sartre, que pela falta, o nada, se revela o ser?

Ver de novo, repetir a experiência visionária não é simplesmente re-ver, mas ver em sua plenitude. Por isso, diz Paz (1982, p. 21), o poema é irrepetível, é único, ao contrário de estilos e gêneros, que se repetem e nos quais, mais uma vez contraditoriamente, o poema se realiza. A experiência do poema é apenas aquela, e não outra: o lirismo é o nome dessa experiência, que pode estar no poema, no romance, no conto, na pintura, na estátua...

Não terá se passado assim com Bentinho, que viu os olhos de Capitu, renovadamente, duas vezes, uma no capítulo XXXII, outra no capítulo CXXIII, e - em cada vez - viu um olhar em que se adivinha, se descobre, se revela algo? Não à-toa esses dois capitulos receberam do narrador o mesmo título, "Olhos de ressaca". No primeiro, o adolescente busca compreender, pelos olhos de Capitu, o mistério que eles têm e que o fazem enamorado; no segundo, pelo olhar dela e por uma lágrima inconveniente diante do morto, o Bento adulto detecta no gesto - gesto, a face - a comprovação do adultério. Nos dois capítulos, uma experiência que tem no olhar a sua fundação; numa palavra: um achado, um procedimento estético. Pois, pelos olhos, o mundo se (re)descobre, e o que parece velho passa a ser, em se tratando de lirismo, completamente novo. Foi assim que Cláudio Manuel da Costa, revendo o pátrio rio, disse, num gesto de espanto, mesmo diante do sobejamente conhecido:

Este é o rio, a montanha é esta,

Estes os troncos, estes os rochedos

$[\ldots]$

Tudo cheio de horror se manifesta,

Rio, montanha, troncos e penedos

Eis aqui espécie de contradição que a literatura dramatiza: o velho é o novo; o "rio" de Cláudio Manuel da Costa, o rio que o viu nascer, é aquele rio antigo e, surpreendentemente, é também "este", que se coloca agora sob o olhar do eu lírico como se somente agora estivesse aparecendo e se dando a conhecer somente, e somente mesmo quando - e porque - o poema o enuncia. Ver de novo coisas antigas ("o rio", "a montanha", "os rochedos"), mas como se fosse a 
primeira vez, é forjar o mundo poético que se lança da voz lírica a enformar o texto. Poesia, no seu sentido mais amplo, é uma maneira de ver, e isso independe de formato do texto, de gênero, de espécie. ${ }^{4}$

Mas o olhar, de tanto sofrer contaminações da redutibilidade ao comum e habitual, termina também por se transformar em tema, além de ser modo de produção literário. Diz Castro Alves: "Teus olhos são negros, negros, / Como as noites sem luar... / São ardentes, são profundos, / Como o negrume do mar". Ou João Cabral de Melo Neto, numa redundância e numa reduplicação da mesma raiz etimológica: "Todos os olhos olharam: / o fantasma no alto da escada, / os pesadelos, o guerreiro morto, / a girl a forca o amor". E, mesmo quando o tema é um sentimento ou uma abstração, a palavra faz-se imagem, porque só como imagem é que se pode assumir a dimensão lírica do texto.

Parecendo estar Camões falando do amor - o lirismo, evidentemente, como venho conduzindo a questão, não se concentra nos temas -, está, na verdade, falando de como se pode falar do amor, defini-lo, recorrendo a cores e imagens. Seu ato é, portanto, uma questão de fundação: é um ato de dizer, de constituir, não de simplesmente comentar um ser do mundo:

Amor é fogo que arde sem se ver

4 Alfredo Bosi, em um ensaio sobre Lima Barreto (2002, p.204-205), coloca ligeiramente essa questão sem querer tratar exatamente do lirismo como o faço neste artigo. Enfocando o capitulo XI de Recordações do escrivão Isaías Caminha - para o crítico, esse capítulo é um "texto de rara beleza"-, mostra, por exemplo, que o encontro dos tempos passado e presente da observação de um casarão, o qual, no momento da enunciação, era uma casa de cômodos barata e decadente e, no passado do enunciado, ao contrário, fora um palacete nobre e elegante, foi responsável pela realização de um momento lírico na narrativa. "A evocação faz contraponto lírico entre o passado e o presente", diz Bosi (grifo meu), o que tornaria esse procedimento de Lima Barreto efetivamente lírico porque "a sua descrição traz, de novo, a originalidade de quem observa as coisas e as pessoas pela primeira vez [...]" (grifo meu). 
O lírico não é simplesmente aquele que se emociona com o mundo - afirmar isso é reconsiderar o truísmo instalado nos manuais de teoria literária mais primitivos. $\mathrm{Na}$ verdade, o lírico diz, assim como Camões disse como o amor pode ser dito; e, nessa atitude, há muito de racional, pois é uma reflexão sobre o dizer. Dá até para pensar, como formulou Kant, que poetas e filósofos, unidos na origem, empreenderam uma atitude expressional comum: à falta de uma linguagem abstrata, os primeiros filósofos se serviram da linguagem sensível dos poetas, não porque, no início, fossem os dois a mesma coisa, mas porque os conceitos abstratos não se teriam constituído logo (SUZUKI, 1998, p. 55).

O lirismo se concentraria, a considerar o raciocínio kantiano, na mescla dos traços da linguagem da filosofia e da poesia, de que 0 sensível e o subjetivo seriam, por assim dizer, configuração, sem que fosse preciso renunciar à racionalidade. ${ }^{5}$ (Camões, no exemplo dado, não só define racionalmente o amor - racionalidade entrevista na série de definições com o verbo "ser", arrumadas simétrica e racionalmente -, mas também o sente como "fogo" e "ferida".) Ajudado pela visão, o único sentido que a modernidade respeitou na divisão e hierarquização dos sentidos, o lírico vê mais ou vê menos, a depender do momento histórico em que se situe, transformando a palavra em imagem. Assim, o barroco não quer ver, porquanto teme perder-se ("Antes, olhos, cegueis do que eu perder-me"); o ainda racionalista maneirista contempla a diversidade ("Amor é fogo... é ferida... contentamento... dor que desatina..."). O poeta concretista, por exemplo, seria, nesse caso, aquele lírico que, bombardeado pela hipertrofia da imagem na contemporaneidade, desconstrói o verbal e, de quebra, esfacela a própria totalidade da imagem. E não há quem não perceba nesse ato uma reflexão sobre o dizer e o constituir da imagem em um século marcado por certa caoticidade visual. Resistência? Dirão alguns que sim, mas não duvidamos disso, ao menos à primeira vista, se se quer manter o ponto de vista histórico-social que cerca o problema.

Às vezes os olhos aparecem atuando metonimicamente, como se recusassem assumir a responsabilidade de configurar a cena lírica,

5 O próprio Kant seria contrário a essa mescla, pois, em filosofia, segundo ele, o entendimento sairia prejudicado $\mathrm{em}$ virtude do apelo ao sensivel. 
mas como, de algum modo e ao mesmo tempo, procurassem desvestila de sua modalidade mais comum, como está em Carlos Drummond de Andrade, que ensaia o despojamento modernista:

Devagar... as janelas olham.

Eta vida besta, meu Deus.

O caráter oral da dicção acentuado no último verso de "Cidadezinha qualquer" remete a um eu que, enfiado naquele ambiente campesino, recorta o banal e, ao mesmo tempo, elege-o motivo do poema, dando-lhe um minuto de glória que só a cena lírica é capaz de dar. E nomear o ato de visão ("Eta vida besta, meu Deus") é o ato do lírico, que não quer simplesmente personalizar a visão ou tão-somente caracterizar a vida rural, mas dizer que o faz. O verso final já extrapola, portanto, a descrição da singela paisagem: trata-se, antes, de uma "consideração do poema", é uma avaliação, é o dizer do lírico que se responsabiliza por esse dizer.

Em narrativa contemporânea, os olhos também são a medida da compreensão, da estupefação e da lucidez: é o que se pode ler nas primeiras linhas de $O$ matador, de Patrícia Melo. Uma personagem que parece estar-se vendo a si mesmo; e, nesse ato ao mesmo tempo surpreendente e fundador de uma nova personalidade, de que rapar 0 bigode é um signo revelador, opera-se, de súbito, uma reatualização do eu:

[...] Mirei o espelho, sem coragem. Fazia cinco anos que eu usava bigode, desde que tinha visto um filme na televisão com o Charles Bronson. Lembrei que minha vida sem bigode tinha sido uma merda, os anjos, Deus, os guardiões do bem, todos ali, no meu bigode. Arlete, ao ver minha indecisão, tomou a navalha das minhas mãos e começou a me barbear.

Em Dom Casmurro, foco desta análise, então, tudo, toda a dramaticidade e revelação e dissimulação converge, segundo o narrador, para os olhos: José Dias disse que Capitu tinha "olhos de cigana oblíqua e dissimulada"; Bentinho criou, para a namorada, a imagem de "olhos de ressaca"; e foi por um olhar dela, já casada, durante o velório de Escobar, que ele, o marido, viu que ela 
contemplava o defunto de modo apaixonado, "que não admira the saltassem algumas lágrimas poucas e caladas...".

Olhos são um lugar-comum da literatura, espécie de canal por onde escoam as análises psicológicas, sociais, ou, mais do que isso, e também, lugar de instauração do procedimento lírico. Olhos também são o lugar do conhecimento, isso na vida, na teoria, na literatura. Lembra-nos a esse respeito o que disse o velho Marx:

Só por meio da relação com o homem Paulo, como seu semelhante, reconhece-se o homem Pedro a si mesmo como homem. Com isso vale para ele também o Paulo, com pele e cabelos, em sua corporalidade paulínica, como forma de manifestação do gênero humano (MARX, 1985, p. 57). ${ }^{6}$

Nesse olhar, Bentinho não queria apenas atingir a compreensão do que pensava e sonhava Capitu, compreendê-la como namorada, mulher ou, se quisermos ir mais longe, ver nela a espécie humana (simulando praticar a teoria do conhecimento marxista), ou tudo isso combinado. Essa é a aparência do texto, pelo menos do ponto de vista da sintaxe e da semântica mais superficial. Parar nesse nível de análise é parar na fábula do texto, não chegar à sua intimidade mimético-discursiva; é deter-se, segundo os termos de Karel Kosik, no mundo fetichizado, que impõe uma interpretação unilateral das coisas. Avaliar assim o texto é tê-lo como ficção barata, que desmerece o esforço desse caprichoso narrador. A corporalidade capituniana não se entrevê fora da corporalidade bentiniana; o enlace dos olhares diz mais que a simples troca de olhares apaixonados. Remete ao discurso, à materialidade do texto, como veremos.

\section{Olhar e linguagem: a visão se faz acontecimento}

Não se trata de qualquer olhar, mas de um olhar que revela, que institui e perfaz. Nesse instante, o mundo parece novo:

6 Eis um belo exemplo, em Marx, de como se pode pensar filosoficamente por meio de imagens sensiveis. Ou de como falou liricamente em texto não-literário: unindo os pólos da objetividade (Paulo e Pedro), fundindoos no reconhecimento mútuo de sua humanidade, tornando nova a visão dessa própria humanidade. 
Eu não sabia o que era oblíqua, mas dissimulada sabia, e queria ver se se podiam chamar assim. Capitu deixou-se fitar e examinar. Só me perguntava o que era, se nunca os vira; eu nada achei extraordinário; a cor e a doçura eram minhas conhecidas. A demora da minha contemplação creio que the deu outra idéia do meu intento $[\ldots]$

Capitu talvez não tenha compreendido - e aí ficaria comprometida, nessa assimetria, a metáfora dos apóstolos formulada por Marx - a verdadeira intenção de Bentinho: o olhar de apaixonado, naquele momento, era menos isso do que o olhar de quem conjuga imagem e palavra, procurando extrair, desse enlace, o sentido que uma metáfora pode assumir no tecido do texto. (A teoria do conhecimento literário teria razões que a própria teoria do conhecimento desconhece?)

Nessa passagem, pode-se até desconfiar que Machado de Assis estaria dramatizando aquilo que Roland Barthes sugestivamente designou como atividade da aranha na organização do tecido poético:

Texto quer dizer Tecido; mas enquanto até aqui esse tecido foi sempre tomado por um produto todo acabado, por trás do qual se mantém, mais ou menos oculto, o sentido (a verdade), nós acentuamos agora, no tecido, a idéia gerativa de que o texto se faz, se trabalha através de um entrelaçamento perpétuo; perdido nesse tecido - nessa textura - o sujeito se desfaz nele, qual uma aranha que se dissolvesse ela mesma nas secreções construtivas de sua teia. Se gostássemos dos neologismos, poderíamos definir a teoria do texto como uma hifologia (hyphos é o tecido e a teia de aranha) (BARTHES, 1977, p. 82-83; os grifos são do autor).

Pobre Capitu que não entendeu ("A demora da contemplação creio que the deu outra idéia do meu intento")! Aquele olhar de Bentinho era o olhar do lírico constituindo a teia do tecido; não era, pelo menos ali, o olhar cego do enamorado que só quer perscrutar os sentidos ordinários da vida (mas o amor "nem é cego / nem setas nem asas tem", já observava Tomás Antônio Gonzaga, no século XVIII). Sua luta era, então, com as palavras, "luta mais vã", como disse o 
outro: vanidade representada pela procura de Capitu, que pertence a outro campo de visão ("e queria ver se se podiam chamar assim"). Quando Capitu, em discurso indireto no romance, inquiriu sobre aquele gesto, apenas queria, orgulhosamente, medir o grau do seu domínio, do seu fascínio sobre o amigo e futuro marido. Mas Bentinho, também narrador, conhecia a estratégia do narrar e constituir, pela narrativa, os sentidos profundos do texto. E, como uma aranha barthesiana, se deixou prender na teia, a ponto de os olhos se transfigurarem:

[Capitu] imaginou que era um pretexto para mirá-los mais de perto, com os meus olhos longos, constantes, enfiados neles, e a isto atribuo que entrassem a ficar crescidos, crescidos c sombrios, com tal expressão que...

A objetividade requerida pelo gênero narrativo é posta em crise: o distanciamento entre narrador e mundo atenua-se, pois os olhos do narrador Bentinho misturam-se aos da amada. Como diz Adorno sobre a posição do narrador no romance contemporâneo, o realismo, imanente à forma narrativa, cede lugar ao subjetivismo, "que não admite mais a matéria intransformada, e com isso solapa o mandamento épico da objectualidade" (ADORNO, 1983, p. 269). Sujeito e objeto elidem-se, como sentenciou Carlos Drummond de Andrade, em "Procura da poesia"?

E, assim - menos épico, mais lírico -, o conjunto verbal desse texto transcrito de Dom Casmurro desvirtua-se em relação aos princípios norteadores do gênero; e liriciza-se, impedindo que o narrador exerça suas certezas ao menos nesse instante. (Nada de pensar que aqui aparece um exemplo lukácsiano de "romantismo da desilusão".) Por isso, os olhos de Bentinho, fonte desse processo, tornam-se "longos" e "enfiados" nos olhos de Capitu, ficando os dele "crescidos, crescidos e sombrios". Um olhar se dissolve, pois, no outro, assim como "a noite dissolve os homens", embora, nessa troca e fusão, Capitu esteja longe dє ser o Paulo ou o Pedro do exemplo de Marx. Tece-se a teia, misturam-se os fios e os olhares. E cada um deles, apesar de manter sua individualidade e intenção diferenciada - ele quer chegar à metáfora do livro, ela quer saber se ele está mesmo tão apaixonado assim -, mescla-se ao outro e se imiscui no outro, levando à fusão, elisão, de sujeito e objeto, que é regra fundamental do procedimento lírico, fazendo os pólos de diálogo perder o distanciamento inerente ao "realismo" exigido pela narrativa. 
O tempo focalizado nesse excerto de Dom Casmurro não é compatível com a análise do enunciado, ou da história. Trata-se do tempo do fazer literário, do enredo, pois é a teia que se está formando: o tecido que, como diz Barthes, não está pronto e acabado, mas se produz enquanto a linguagem avança, levando os olhos, no caso aqui explanado, a meter-se um no outro. O sujeito, diz ainda Barthes, "se desfaz" enquanto o texto "se faz". Enredado na teia ("teia", "luz balão", de João Cabral de Melo Neto?), Bentinho tem os olhos deformados, aumentados, dissolvidos naqueles outros olhos. E, nesse movimento, dramatiza-se a busca da expressão capaz de traduzir o instante lírico: expressão que não nasce centrada nos olhos de Capitu, porque o moderno perdeu definitivamente o centro (dai a indagação, a procura dramática - quem socorrer há de?). Sugestivamente, por isso mesmo, esse momento focalizado em Dom Casmurro "termina" por uma interrupção, um súbito balbucio representado na escrita pelas reticências que fecham (fecham?) o parágrafo:

\section{[...] com tal expressão que...}

Essa representação do achado ou do instante retórico, que aqui chamo de ante-sala da euresis, é o que se tem denominado, em teoria do discurso, de "acontecimento" - o que reforça, em teoria do texto (poético ou não), a idéia de que o tecido se tece à medida que se lê ou se (re)escreve, ainda no sentido barthesiano. $\mathrm{O}$ acontecimento da linguagem, em explicação de Carlo Diano (apud BOSI, 1988, p. 275), é "aquilo que acontece para alguém"; então, "para que haja um evento é necessário que esse acontecer eu o sinta como um acontecer para mim".

A Bentinho abre-se, de repente, o rol de sugestões discursivas, surgidas enquanto ele espera o evento fazer-se, enquanto procura, busca e... interrompe-se ("com tal expressão que..."). Assim, fica definido que o tempo assinalado nesse trecho de Dom Casmurro apesar do uso contínuo dos pretéritos "tinha-me lembrado", "sabia", "deixou-se fitar", "perguntava", "eram", "deu" - é, de fato, o tempo do discurso acontecimental, algo que fica mais claro apenas quando, abruptamente, o narrador evolui para um brilhante presente enunciativo de uma forma verbal que é o comentário feito pelo narrador acerca do que passou: "e a isto atribuo que entrassem a ficar crescidos". Comentário e ação, no dizer de Adorno (op. cit., p. 272), 
terminam por entrelaçar-se, fazendo desaparecer a distância entre o narrador e o narrado e o leitor.

Diz ainda Diano:

Como aquilo que sobrevém (ou aparece, produz-se, dáse: outros modos de ler évenit) a alguém, o evento é sempre hic et nunc. Um raio golpeou uma árvore durante a noite, mas eu só o vejo pela manhã. $O$ fato, caso venha a constituir para mim um evento, só o será quando o que "aconteceu" se fizer atual como um "acontece" [...] (apud BOSI, 1988, p. 275).

O evento assinala o nunca visto, o nunca vivido: um ato singular do sujeito que não se repete (como lembra Octavio Paz, o ato poético é único, irredutivel).

O que parecia ser, pois, um movimento da fábula simplesmente, com marcação do tempo do enunciado - todos no pretérito, como vimos, o tempo do passado visto por quem rememora um tempo que já acabou -, pouco a pouco revela sua face de evento, de discurso, de presente narrativo: "e a isto atribuo que entrassem a ficar crescidos". Nessa súbita passagem de tempos, do da história para o do enredo, entremostra-se igualmente a separação do plano objetivo (o tempo de um fato que já passou) e do subjetivo (o passado cede ao presente narrativo) tanto quanto sua sutil diluição. E, em troca, eleva-se, pela fusão desses mesmos planos, a passagem analisada à sua condição lírica, instância em que a voz que se ouve no romance perde, subitamente, a densidade narratorial, mesmo em um narrador de primeira pessoa, como este Bentinho-Dom Casmurto, supremo advogado de si mesmo, que é cioso em tudo querer esquadrinhar, julgar e saber, do alto de seu chapéu, e em não querer perder um só detalhe desse passado torturante.

Por isso, de repente, eis que ele amolece em sua lembrança, balbucia, não consegue completar a frase ("com tal expressão que..."). A voz enlanguesce, minimaliza-se, torna-se quase inaudivel. Decai um pouco, assim, a sua firmeza de advogado feroz, e surge a do patriarca ofendido, enquanto, nessa revisão dos fatos vividos, Bento-Dom Casmurro se submete ao jogo de espelhos e de palavras que só aparentemente se repetem ("Olhos de ressaca" é nome de dois capítulos), como só aparentemente também se repete a feição arquitetônica da casa da Rua de Mata-cavalos ("não consegui 
recompor o que foi nem o que fui. Em tudo, se o rosto é igual, a fisionomia é diferente", diz ele no segundo capítulo do romance, referindo-se à casa-túmulo do Engenho Novo). Nem poderia ser de outro modo: aprendemos na Retórica que a repetição não é a produção do mesmo, não é simples reprodução; repetir, repetere, é perseguir o sentido. Luta vã para o eu que luta, mas, sem dúvida, é novo lampejo na visão. Fracasso na vida; vitória no discurso poético.

Aliás, essa é, como vimos insistindo desde o começo, a lição de Aristóteles ao falar da mimese: não é cópia, não é reprodução, mas execução. A poesia nasce da surpresa de uma visão que não quis conformar-se ao já-visto:

Prova disso é o que acontece na realidade: das coisas cuja visão é penosa temos prazer em contemplar a imagem quanto mais perfeita; por exemplo, as formas dos bichos mais desprezíveis e dos cadáveres (ARISTÓTELES, 1997, p. 22).

Não há, pois, identidade entre o que se passa no mundo e seu similar no texto literário. Um não é a tradução exata do outro. A imagem (por exemplo, a casa do engenho Novo que "reproduz" a de Mata-cavalos; o título "Olhos de ressaca", do capitulo CXXIII, que reproduz o do capítulo XXXII) é sempre um dado novo: sua expressão e consideração auto-reflexiva, o evento de linguagem lírica.

Não estaria aí, em germe, nas palavras do Estagirita, uma teoria do evento literário-discursivo?

$\mathrm{Na}$ cena que estou analisando - cena lírica, decerto, atitude, procedimento poético, auto-reflexibilidade do discurso -, colocam-se como antípodas, em se tratando de consciência, as duas personagens que serão antípodas a vida toda: Bento e Capitu. Esta, voltada para a vida em toda sua efervescência; aquele, reflexivo, produtor de poesia. Ela, comum, sem verticalidade de vivências e pensamentos; ele, profundo em sua visão das coisas e dotado de sensibilidade lírica. Como disse semelhantemente Manuel Bandeira, em um pocma de todo sugestivo intitulado "Momento num café":

Quando o enterro passou

Os homens que se achavam no café

Tiraram o chapéu maquinalmente 
$[\cdots]$

Um no entanto se descobriu num gesto largo $\mathrm{e}$ demorado Olhando o esquife longamente

Este sabia que a vida é uma agitação feroz e sem finalidade

Que a vida é traição

$[\ldots]$

Em um "momento" - momento do discurso, e não da historieta narrada no poema -, pôde-se descobrir o que parece estar sendo visto pela primeira vez: o enterro, algo banal no cenário urbano, motivou, no entanto, o vislumbre de que a vida, muito além de sua corriqueirice, é "sem finalidade". Os outros, que bebiam e estavam absortos, sem notar a gravidade e o alcance do instante, viam normalmente sentido na vida mundana, na alegria do bar, no encontro de amigos: situação interrompida pela passagem do esquife, a que respondem maquinalmente com um tirar de chapéus. Mas o olhar longo de um deles no café, longo demais para um instante tão fugaz mais uma vez o olhar, menos como tema e mais como demarcação da expressão -, tem a profundidade do olhar de Bentinho. E, ao intitular o poema de "Momento num café", o eu dramatiza e nomeia inconfundivelmente o acontecimento lírico... Um momento, pois; a fixação de uma compreensão da vida inteira em um momento, como se, nessa interrupção da alegria cotidiana do café, simbolizada pela passagem do enterro pela rua, se pudesse ver, pela primeira vez, o sentido da totalidade da existência. Um momento apenas.

Momento que congelou a ação, tanto nesse poema de Manuel Bandeira quanto no trecho de Dom Casmurro para o qual chamo a atenção. Bem a propósito, soa bem a observação de Lafetá (2004, p. 31) ao destacar esse processo - a imobilização de um momento -, contrapondo a natureza do lírico à do épico, na leitura que fez do romance $O$ amanuense Belmiro: "O lirismo é imóvel, por representar a fixação definitiva, no espirito, de um momento. A épica é ação".

O que Capitu não entendeu é que, naquele olhar de Bento, estava o momento de fundação da imagem lírica decisiva para a compreensão da metáfora que domina a economia do livro inteiro, imprescindivel para a compreensão da longa teia que se tece no romance: "olhos de ressaca". Capitu \& os amigos do bar do poema de 
Manuel Bandeira são, nessa comparação, todos iguais, mero pano de fundo para a constituição do processo lírico. Bentinho, qual o eu lírico de uma poesia que se escreve longamente, produz o instante decisivo que vai reger e nortear esse romance-poema.

O que evidencia também que Capitu esteve, nesse episódio, iludida quanto às investidas de Bentinho. Este, se não por acaso se mostra como vítima da história ("a minha primeira amiga e o meu maior amigo, tão extremosos ambos e tão queridos também, quis o destino que acabassem juntando-se e enganando-me...", diz ele no fim do romance), muda de posição quando, nessa assimetria, é visto como dono da história, transformando Capitu em vítima do seu discurso infernal, que ela, de resto, não entende nem parece alcançar.

Como uma aranha, o narrador-personagem tece, e, ao fazer a teia, nela se perde, revelando a ambigüidade de sua participação no romance, ora como narrador, ora como personagem. Isso justifica a sua divisão em dois: ora Bentinho, ora Dom Casmurro. O que nos faz lembrar a metáfora de Marx sobre o ato do conhecimento (Paulo e Pedro reconhecem-se mutuamente como homens nas trocas que realizam). A visibilidade de um é o apagamento momentâneo do outro, e só uma leitura que preveja a dialeticidade das coisas é que pode apanhar isso no ar. Por isso é que, ao contrário do que se dá entre os apóstolos, uma vez que a linguagem do romance é a linguagem do fracionamento do mundo,

[...] entre Bentinho e Dom Casmurro nenhuma unificação é possível. Em Bentinho, Dom Casmurro não se reconhece, como não se reconhece no rosto do filho, onde encontra o do amigo Escobar, o antigo colega com que, supostamente, Capitu o traíra. No entanto, acredita reconhecer, na menina Capitu, a adúltera que talvez não passe de uma invenção sua, dando-nos a pista da astúcia de Machado de Assis, que induz o leitor a tomar a versão do advogado como a verdadeira, para fazê-lo cair no engano de uma leitura realista da narrativa de Dom Casmurro, embora dando também, ao fazê-lo narrador, os elementos para se duvidar dessa versão. (MURICY, 1988, p. 115-116). 
O próprio título do romance é outra reduplicação enganosa, pois Dom Casmurro não é Bentinho, assim como a casa do Engenho Novo, apesar da intencional reduplicação, não é a de Mata-cavalos. Cadeia de enganos - talvez, como podemos chegar a pensar, tudo seja invenção desse espírito de aguçada subjetivação em progressivo tormento. Como que ambigüidade máxima instalada na fábula, revelase o cruzamento dos planos. Intermedeia essa duplicidade aparente a consciência aguda do narrador-poeta, que só nessa instância tem o domínio completo do fazer lírico, que avulta em sua condição de processo, de euresis, de acontecimento.

\section{Eureca! Olhos de ressaca!}

Dando prosseguimento à cena do capítulo XXXII, Bentinho, logo após a hesitação, espera, balbucia, pede à retórica dos namorados como quem pede às musas a inspiração para sua poesia:

Retórica dos namorados, dá-me uma comparação exata e poética para dizer o que foram aqueles olhos de Capitu. Não me acode imagem capaz de dizer, sem qucbra da dignidade do estilo, o que eles foram e me fizeram.

Prevejo aí, pois, um momento crucial dentro da narrativa, espécie de momento de partenogênese literária, onde o que mais importa é a produção da linguagem que, auto-refletida, olha só para si mesma, porquanto é assim que o discurso literário se reinventa e atinge o ponto mimético máximo. É assim, então, que, como afirma Antonio Candido, o momento da construção do texto literário engendra os chamados objetos autônomos (CANDIDO, 1995, p. 244$245),{ }^{7}$ idéia em tudo distante da noção de "arte pela arte" ou algo que o valha. O caráter construcional do texto, sim, é que importa ao crítico, pois só ai se revela o quanto de esforço humanizador foi investido na realização do texto, para que possa ser compreendido como literatura. O que não impede, obviamente, que se veja nesse movimento outro sentido: o fetiche da auto-referenciação - esse apelo à velha retórica que na época de Machado de Assis já estava em pleno descrédito - corresponde à ironia metódica de quem desnuda o próprio

\footnotetext{
${ }^{7}$ Cf. essa discussão sobre o caráter construcional, expressional e cognitivo do texto literário em Pareyson (1997).
} 
ato de auto-referir-se e que, em Machado, resulta em mais uma de suas antífrases.

Mas, como Bentinho é figura moderna, não pode ficar esperando que uma voz do além the envie a imagem justa. Espécie de provocação machadiana, a apóstrofe à "retórica dos namorados" é mais um desses enganos sutilmente urdidos (um cínico olhar para cima, para o céu retórico), e Bentinho reaparece $\mathrm{em}$ toda sua humanidade (um perscrutador olhar para baixo, para Capitu), enunciando a metáfora que é o núcleo do entendimento ao mesmo tempo da fábula e do enredo - se é que alguma unificação, como diz Muricy (1988, p. 115), é de fato possível nesse romance:

Olhos de ressaca? Vá, de ressaca. É o que me dá idéia daquela feição nova.

Numa tentativa de achar a expressão exata ("Olhos de ressaca? Vá, de ressaca."), o narrador finge produzir, como num estalo, tal metáfora só nesse momento, simulando espanto e naturalidade de uma só vez. Momento que suspende a ação do romance. A realidade, mesmo conhecida, surge-lhe incomum ("É o que me dá idéia daquela feição nova."). Bentinho, através desse presente discursivo, com que abandona totalmente os movimentos lineares da fábula, faz nascer algo que só agora consegue ver: os velhos e amigos olhos de Capitu são, agora, para ele, ${ }^{8}$ olhos de ressaca. E isso não é efeito da emoção pura, como pode parecer a um espírito menos avisado das manhas da realização literária; ${ }^{9} 0$ lirismo não é sinônimo de efusão subjetiva - retomando as palavras de Pinson (confira a nota 1 deste artigo) - mas é o momento máximo em que a linguagem é colocada sob tensão, a linguagem informa sua capacidade

8 Não é justamente isso o que diz Carlo Diano sobre o evento? "[...] para que haja um evento é necessário que esse acontecer eu o sinta como um acontecer para mim" (grifo meu).

9 Nesse sentido é que se pode dizer que Capitu é uma espécie de leitor pobre da literatura, pois se volta para os movimentos da fábula do romance e não para os da trama ou enredo. Enfim, não atinge o ponto nevrálgico da constituição literária, que se concentra no dizer e fazer o tecido da aranha bartesiana. Para mim, o momento alto do lirismo, momento de demonstração - e nomeação - da realização mimética. 
de nomear, encontrando, assim, a sua razão de ser. Pobre Capitu, que não entendeu isso!

Carentes, pois, de precisão conceitual mas dotados de forte ressonância poética, estes olhos anunciam os outros olhos de ressaca, aqueles do capítulo CXXIII, os quais, por sua vez, naquele outro instante, são igualmente novos. Novos porque já não são vistos pelo namorado ingênuo, mas pelo marido ciumento, corrosivo, às portas definitivas da casmurrice (como novo parece ser o velho rio de Cláudio Manuel da Costa, no poema aqui citado, páginas atrás).

Se no capítulo XXXII a interferência do mar na composição da imagem é sinônimo de mistério e encanto,

Traziam não sei que fluido misterioso e enérgico, uma força que arrastava para dentro, como a vaga que se retira da praia, nos dias de ressaca

agora, no capítulo CXXIII, o mar confirma metaforicamente uma dolorosa suspeita, que ao longo do texto se transforma em certeza de casmurro:

Momento houve em que os olhos de Capitu fitaram o defunto, quais os da viúva, sem o pranto nem palavras desta, mas grandes e abertos, como a vaga do mar lá fora, como se quisesse tragar também o nadador da manhã.

Em um capítulo, o mar é uma deliciosa abstração (os namorados adolescentes estavam na sala da casa, sem a presença física do mar); em outro, o mar está ali, defronte à casa do amigo ("o mar lá fora"), testemunhando o drama do protagonista envenenado. Em um capítulo, o mar é, por conseguinte, motivo lírico, evento de linguagem que engendra a metáfora, como a aranha tece o tecido; em outro, o mar já é definitivamente espaço do enunciado, está ali, ao alcance da vista de todos, inclusive da de Sancha, e, como tal, perde sua força produtora. Não dizia Freud que só se deseja na ausência do objeto?

Assim, uma mesma imagem pode ser instrumento de deflagração de um processo retórico - cá entre nós, de processo lírico, capaz de gerar um mundo novo, nunca habitado antes, malgrado o desgaste da imagem do mar, espécie de topos literário - e, em outro instante, pode ser tão-somente um componente figurativo do cenário, 
da composição do espaço, da personagem, do tempo, sem maiores ambições senão o de se colocar no plano de visualidade do leitor, qualquer que seja a intenção dessa figuração. No primeiro caso, eis um acontecimento de linguagem; no outro, um elemento descritivo, um pormenor composicional.

O texto não é, pois, apenas uma história que se conta (a ser assim, não seria literária, muito menos poética). O objeto novo, de que fala Candido, a sua irrepetibilidade, que Octavio Paz destacou na linguagem da poesia, o lirismo como acontecimento - de que a visão súbita, entretecida no discurso, é seu medium mais representativo, porque antes de tudo é procedimento - só ocorrem mesmo quando o lirismo assume a direção da cena e a poesia imita ações (aristotelicamente falando), que são, antes de tudo, ações de uma linguagem efetivamente construída e capaz de dizê-lo.

\section{Referências}

ADORNO, Theodor. Posição do narrador no romance contemporâneo. In: ADORNO, Theodor; BENJAMIN, Walter et al. Textos escolhidos. Tradução José Lino Grünnewald et al. 2 ed. São Paulo: Abril Cultural, 1983. p. 269-273.

ARISTÓTELES; HORÁCIO; LONGINO. A poética clássica. Tradução Jaime Bruna. 7. ed. São Paulo: Cultrix, 1997.

BARTHES, Roland. O prazer do texto. Tradução Jacob Guinsburg. São Paulo: Perspectiva, 1977.

BOSI, Alfredo. Poesia resistência. In: BOSI, Alfredo. O ser e o tempo da poesia. São Paulo: Cultrix; Ed. da Universidade de São Paulo, 1977. p. 141-192.

BOSI, Alfredo. $\Lambda$ interpretação da obra literária. In: BOSI, Alfredo. Céu. inferno: ensaios de crítica literária e idcológica. São Paulo: Ática, 1988. p. 274-287.

BOSI, Alfredo. Figuras do $e u$ nas recordações de Isaías Caminha. In: BOSI, Alfredo. Literatura e resistencia. São Paulo: Companhia das Letras, 2002. p. 186-208. 
CANDIDO, Antonio. Literatura e sociedade: estudos de teoria e história literária. 5. ed. São Paulo: Companhia Editora Nacional, 1976.

CANDIDO, Antonio. O direito à literatura. In: CANDIDO, Antonio. Vários escritos. 3. ed. rev. e ampl. São Paulo: Duas Cidades, 1995. p. 235-263.

KOSÍK, Karel. Dialética do concreto. Tradução Célia Neves; Alderico Toríbio. 2. ed. Rio de Janeiro: Paz e Terra, 1976.

LAFETÁ, João Luiz. À sombra das moças em flor: uma leitura do romance $O$ amanuense Belmiro, de Cyro dos Anjos. In: LAFETÁ, João Luiz. A dimensão da noite e outros ensaios. São Paulo: Duas Cidades; Ed. 34, 2004. p. 19-37.

LUKÁCS, Georg. Teoria do romance. Tradução Alfredo Margarido. Lisboa: Presença, 197-.

MARX, Karl. O capital: crítica da economia política. Tradução Regis Barbosa; Flávio R. Kothe. 2. ed. São Paulo: Nova Cultural, 1985. v. 1. MURICY, Kátia. A razão cética: Machado de Assis e as questões de seu tempo. São Paulo: Companhia das Letras, 1988.

PAZ, Octavio. O arco e a lira. Tradução Olga Savary. 2. ed. Rio de Janeiro: Nova Fronteira, 1982.

PAREYSON, Luigi. Os problemas da estética. Tradução Maria Helena Nery Garcez. 3. ed. São Paulo: Martins Fontes, 1997.

PERRONE-MOISÉS, Leyla. Inútil poesia: e outros ensaios breves. São Paulo: Companhia das Letras, 2000.

PINSON, Jean-Claude. À quoi bon la poésie aujourd'hui?. Nantes: Éditions Pleins Feux, 1999.

SILVA, Vitor Manuel de Aguiar e. Teoria da literatura. São Paulo: Martins Fontes, 1976.

SUZUKI, Márcio. O gênio romântico: crítica e história da filosofia em Friedrich Schlegel. São Paulo: Iluminuras, 1998. 